\title{
Tourism Destination Competitiveness: an application model for the south of Portugal versus the Mediterranean region of Spain: COMPETITIVTOUR
}

\section{Competitividade de Destinos Turísticos: um Modelo de Aplicação para o sul de Portugal versus as regiões Mediterrânicas de Espanha: COMPETITIVTOUR}

\author{
Fernando Perna \\ University of Algarve, School of Management, Hospitality and Tourism, Campus da Penha, 8005-139, Faro, Portugal, \\ fperna@ualg.pt
}

\author{
Maria João Custódio \\ University of Algarve, School of Management, Hospitality and Tourism, Portugal, mjcusto@ualg.pt
}

Vanessa Oliveira

University of Algarve, School of Management, Hospitality and Tourism, Portugal, voliveira@ualg.pt

\begin{abstract}
Tourism destination competitiveness analysis benefits from a growing number of theoretical and applied developments. To support competitiveness strategies and despite the paraphernalia of competitiveness indexes available, there is not just a single set of indicators that can be used for all destinations at all times. The COMPETITIVTOUR model, developed since 2009 is applied to the south of Portugal versus the Mediterranean regions of Spain, a geographical area that aggregates 14 provinces, 20.2 million inhabitants and 180.1 million overnight stays. COMPETITIVTOUR's objective is to create and apply a territorial assessment model, adapted to the common specificities of these regions, aiming to assist in guiding the complex task of destination competiveness management, with inputs from 25 official producers of information from Portugal and Spain. The outputs are aggregated in three main topics: territory management, markets, and resources\&products. Critical areas were identified, with emphasis on the growing seasonality of demand, the market demand and supply adjustment and accommodation prices.
\end{abstract}

Keywords: Tourism destination, competitiveness, territory management, evaluation models, West Mediterranean coast.
Resumo

A análise da competitividade do destino turístico beneficia de um número crescente de desenvolvimentos teóricos e aplicados. Para apoiar as estratégias de competitividade e apesar da parafernália dos índices de competitividade disponíveis, não há apenas um único conjunto de indicadores que podem ser usados para todos os destinos em todos os momentos. O modelo COMPETITIVTOUR, desenvolvido desde 2009, é aplicado ao sul de Portugal e em relação às regiões mediterrâneas de Espanha, uma área geográfica que agrega 14 províncias, 20,2 milhões de habitantes e 180,1 milhões de dormidas. O objetivo do COMPETITIVTOUR é criar e aplicar um modelo de avaliação territorial, adaptado às especificidades comuns dessas regiões, com o objetivo de orientar a complexa tarefa de gestão da competitividade do destino, com dados de 25 produtores oficiais de informação de Portugal e Espanha. Os resultados são agregados em três tópicos principais: gestão de territórios, mercados e recursos e produtos. Foram identificadas áreas críticas, com ênfase na sazonalidade crescente da procura, na procura do mercado e no ajuste da oferta e preços do alojamento.

Palavras-chave: Destino turístico, competitividade, gestão do território, modelos de avaliação, costa oeste do Mediterrâneo.

\section{Introduction}

The fundamental task of destination management is to understand how a tourism destination's competitiveness can be enhanced and sustained, particularly merging the tourist experiences and the territory attractions as an instrument to improve the residents' quality of life. The reason for the increased attention competitiveness is receiving in the tourism literature is, according to Croes (2011) mainly due to three reasons: increasing importance from the tourism sector in global, national and regional economies, increase in the competition and pressure among destinations and the fact that the benefits from tourism in the short term can be clearly analyzed although in the long term they are not so evident.

The guiding principles of the COMPETITIVTOUR is that destination management support decision systems should compare what can be compared, and destination competiveness is an issue played mostly at a regional level. As an example, tourist profiles differ from sun and sea to urban and cultural demand (Buhalis, 2000), and inside the borders of a country it is possible to find large differences in the demand flows and competitiveness levels of its regions despite the average competitiveness status of the country (IMPACTUR 2015; WEF 2015). Within the framework of territory competitiveness and measurement, the purpose is to develop a conceptual model for destination competitiveness assessment at a regional level, theoretically consistent and empirically feasible, based on the requests of the Algarve destination and territory management requirements delivered by the Regional Commission of Coordination and Development of Algarve (CCDRA), a decentralized office of the Ministry of Agriculture, Sea, Environment and Spatial Planning of the Portuguese Government, responsible for the implementation of the environmental policies, spatial and city planning and regional development. The research was supported by CCDRA and is being carried out by the International Centre of Tourism and Territory Research of the University of Algarve. 
The objectives of the COMPETITIVTOUR model resumed in this paper are as follow:

- Debate destination competitiveness literature analyzing a matrix of reference models, therefore exploring a more suited and objective method to analyze tourism competitiveness at a regional level;

- Develop a model to be applied in a systematic timely framework, thereby using a limited number of existent and regularly produced indicators to the destinations in study;

- Develop a model that can be used either as a global tool in competitiveness assessment but also allows each of the indicators of the region to be looked individually in order to easily detect and prevent possible issues.

The special scope elected was the Algarve, the southern region of Portugal and the most important Portuguese tourism destination when measured and balanced the total lodging overnights stays and revenues, respectively 14.468.630 overnights stays / 33.2\% of Portugal and $€ 702.4$ million / 31.8\% of Portugal (IMPACTUR 2015), and the 13 southern Mediterranean provinces of Spain, including the Balearic Islands, whose territories' average dimension, Mediterranean climate, tourism specialization in sea\&sun product, mature life cycle stage, - with some urban/cultural destination exceptions - guarantees a general comparable destination framework that struggles to capture mostly the same source markets: national, United Kingdom and Germany, and in a second group France, Ireland and the Netherlands.

As a result of the research assumptions and context, the paper structure undertakes a first theoretical approach, Chapter 2, in which an up-to-date discussion about tourism destination competitiveness concepts takes place, assuming it as one of the main areas of interest in tourism's literature. Facing the necessity to measure destination competitiveness, Chapter 3 completes the theoretical approach which summarizes and compares destination competitiveness reference models. The specificities of COMPETITIVTOUR model are systemized along Chapter 4, with its positioning, methodology, results and main findings discussed for the Portuguese and Spanish Mediterranean provinces. Finally, in Chapter 5, the conclusions and appeal for future developments are presented.

\section{Tourism Destination Competitiveness}

Competitiveness is a key concept in the relation between environment, territory and population. Its definition is based upon the Organization for Economic Co-operation and Development's - OECD position, in which it is referred as the ability of a place to deliver goods and services (considering free and fair conditions) in global markets "...while simultaneously maintaining and expanding the real incomes of its people over the long term" (OECD, 2005:17). On the other hand, according to Crouch and Ritchie (1999), the problem in the definition of competitiveness resides in the fact that it is a comparative concept (competitive compared to what?) and multidimensional (which salient characteristics?). In the center of this problematic Porter (Porter, 1990) has become an initial major influence, the author considers competitiveness as essential to the success of both companies and territories.

Considering the economic impact of tourism, the tourism industry came to be regarded as a powerful economic source for many countries and regions all over the world (Kayar \& Kozak, 2010), a specialization matrix in which the territories need to constantly brace and attract new demand flows but, simultaneously, must deal with carrying capacity issues even more stressed in stagnated life cycle destinations. Acting in a globalized and dynamic market, it becomes evident that the success of tourism destinations is influenced by their relative competitiveness (Enright and Newton, 2004). Tourism destinations or territories specialized in tourism can be defined as "amalgams of tourism products, offering an integrated experience to consumers" (Buhalis, 2000, p. 97), being the fundamental product the destination experience as a combination of products, services and experiences locally provided. It is considered that, although competition can and does occur between single actors of the tourism industry (airlines, hotels, tour operators ...), it is centered on the destination as the inter-enterprise competition is dependent upon the choices the consumer makes between alternative destinations (Crouch \& Ritchie 2000).

As destinations strive for bigger market shares, there is an increasing competition in the tourism industry and determining the level of competitiveness becomes crucial to measure the performance of a destination compared to its competitors (Croes \& Kubickova, 2013). Associated with this growing competition are the substantial changes that are taking place globally, influencing the kinds of experiences that tourists seek (Dwyer, Armensk, Mihalič \& Cvelbar, 2014). These authors argue that a key element of a successful tourism industry is the ability to recognize and deal with change across a wide range of key trends and the way these trends interact, "a destination is competitive if it can attract and satisfy potential tourists and this competitiveness is determined both by tourism-specific factors and by a much wider range of factors that influence the tourism service providers" (Enright \& Newton, 2004, p. 778). Bornhorst, Ritchie \& Sheehan (2010) mention that competition among tourism destinations continues to intensify, with the substitution effect among destinations requiring the ability to effectively manage all components of the tourism system to ensure that a competitive advantage is created and maintained. As tourists gain experience in other destinations, which are directly or indirectly in competition, their perceptions of quality and overall performance will play a significant role in determining 
repeat business or positive word-of-mouth recommendation. Implicitly, tourists make comparisons between facilities, attractions and service standards of various destinations (Kozak \& Rimmington, 1999). Hanafiah, Hemdi, and Ahmad (2015) underline competitiveness as one of the essential elements in the tourism industry foundation, being a critical concept in assisting tourism development, destination management and tourism strategies planning. Buhalis (2000) considers tourism destinations as some of the most difficult entities to manage and market, due to the wide variety of stakeholders involved in the tourism product development, production and delivery, and the complex interests and relationships between them, being that competitiveness in a tourism destination context means different concerns to different people (Ayikoru, 2015). The central aspect is the destination's capacity to ensure their overall appeal and that the tourist experience offered is superior to that of alternative destinations, considering that "economic growth and competitiveness involve a complex interactive process of social, political and institutional change" (Dwyer \& Kim, 2003, p. 370). The authors defend that there is not one general theory that can support the process. Perspectives of competitiveness from various disciplines reveal a complex and multi-faceted concept that also stresses the need to focus on a model that although based on more general models, has to be dedicated to the tourism sector, as its nature differs from more traditional products and services. Therefore, establishing an evaluation model and selecting an evaluation method is a required and complex task in order to evaluate tourist destination competitiveness (Chien-Minn, Sheu-Hua, Hong-Tau, \& Tsung-Hsien, 2016).

As a result, since the final 90s until today, destination competitiveness concept and application emerged and stands as one of the main areas of interest in tourism's literature, attaining a growing interest among the scientific community. Works as Kozak and Rimmington (1999), Crouch and Ritchie (1999), d'Hauteserre (2000), Go and Govers (2000), Buhalis (2000), Hassan (2000), Dwyer and Kim (2003), Enright and Newton (2004), Zhang, Gu, Gu and Zhang (2011), Croes (2011), Crouch (2011), Huang and Peng (2012), Dupeyras and MacCallum (2013), Croes and Kubickova (2013) and Webster and Ivanov (2014) should also be mentioned. The territory management continuously demands for competitiveness conceptual guidelines and empirical essays, being that competitiveness cannot be measured directly, indicators have to be used to the effect (Croes \& Kubickova, 2013). A variety of indicators that cover a large number of factors have already been proposed in the literature, a domain that results in the next research step focused on the destination's competitiveness models.

\section{Destination Competitiveness Models}

Competitiveness models can be divided into three main research areas (Crouch, 2011). In the first place, there are a group of models that have the aim of diagnosing competitive positions of specific destinations. There are a second group of models that focus on particular aspects of a destination's competitiveness, as the destination's positioning or management systems. The third and last group aggregates general models and theories that are not centered in specific attributes or destinations. Probably as a result of a demand for wide range application models, the most broadly used type is concentrated in the third group, with emphasis in the major works developed by Crouch and Ritchie (1999), Dwyer and Kim (2003), World Economic Forum (2007) and, recently, Sánchez and Lopéz (2015), whose factors are summarized in Figure 1. More recently there are a number of studies that focus on the causal relationship to the dependent variable, factor interaction and relative weights of the different indicators in the overall competitiveness index (Croes, 2011, Zhang et al., 2011 and Huang \& Peng, 2012).

According to Mazanec and Ring (2011), for an index to achieve its objectives it has to use competitiveness variables that exhibit significant relationships with tourism performance criteria. Although most destination competitiveness models used in the tourism literature rest on Porter's (1980) five forces of competitiveness and Porter's (1990) diamond of national competitiveness, there is an extensive research involved both in understanding and explaining destination competitiveness and in the development and application of destination competitiveness models. Within this context, as presented in figure 1 , some models are strongly concentrated in the conceptual consistence of the approach such as Crouch and Ritchie (1999) and Dwyer and Kim (2003), who aim to support worldwide developments and applications, while others, more rigid in the guidelines, point to the delivery of an annual national competitive index such as WEF (2007). 
Figure 1 - Competitiveness Destination Factors: Central Models and Indexes

\begin{tabular}{|c|c|c|c|}
\hline \multicolumn{3}{|c|}{ Destination Competitiveness Model } & \multirow{2}{*}{$\begin{array}{c}\text { Competitiveness Index } \\
\text { World Economic Forum (2007) } \\
\text { Type: Applied } \\
\end{array}$} \\
\hline $\begin{array}{l}\text { Crouch and Ritchie (1999) } \\
\text { Type: Conceptual } \\
\end{array}$ & Dwyer and Kim (2003) & Sánchez and López (2015) & \\
\hline Comparative Advantages & Resources & Morphology & $\begin{array}{l}\text { T\&T Human, Cultural and } \\
\text { Natural Resources }\end{array}$ \\
\hline Human Resources & Endowed Resources & Interest Places LIC & Human Resources \\
\hline Physical Resources & Created Resources & Number of Beaches & Affinity for T\&T \\
\hline Knowledge Resources & Supporting Resources & & Natural Resources \\
\hline Capital Resources & & Meteo & Cultural Resources \\
\hline Infra. and Tourism Superstructure & & Summer Average Temperature & \\
\hline Historical and Cultural Resources & & Hours of Sunlight & \\
\hline Competitive Advantages & Destination Competitiveness & Cultural & \\
\hline Audit \& Inventory & Dest. Competitiveness Indicators & Libraries & \\
\hline Maintenance & & Edited Books & \\
\hline Growth and Development & Situational Conditions & Museums & \\
\hline Efficiency & & UNESCO places & \\
\hline Effectiveness & Demand & & \\
\hline & & Attractiveness & \\
\hline Support. Factors and Resources & & Large Department Stores & Environment and $\mathrm{T} \& \mathrm{~T}$ Business \\
\hline Infrastructure & & Music Festivals & Infrastructure \\
\hline Accessibility & & Golf Clubs & Air Transport Infrastructure \\
\hline Facilitating Resources & & Tennis Clubs & Ground Transport Infrastructure \\
\hline Enterprise & & Zoos & Tourism Infrastructure \\
\hline Core Resources and Attractions & & Theme Parks & ICT Infrastructure \\
\hline Physiography & & Hotel Rooms & Price Competitiveness in the T\&T \\
\hline Culture \& History & & LFP Football Teams & Industry \\
\hline Market Ties & & & \\
\hline Mix of Activities & & Services & \\
\hline Special Events & & Bank, Central Bank and Saving Bank Branches & \\
\hline Superstructure & & Hospital & \\
\hline & & Flight Companies & \\
\hline Destination Management & Destination Management & Cruises & T \& T Regulatory Framework \\
\hline Resource Stewardship & Government & Road Kilometres & Policy rules and regulations \\
\hline Marketing & Industry & Port Authorities & Environmental sustainability \\
\hline Organization & & & Safety and Security \\
\hline Information & & Specialization & Health and Hygiene \\
\hline Service & & $\begin{array}{l}\text { Foreign Tourism Weight } \\
\text { Tourism Quote }\end{array}$ & Prioritization of T\&T \\
\hline Qualifying Determinants & Socioeconomic Prosperity & Hotel Ocupancy Rate & \\
\hline Location & Quality of Life Indicators & Price Index (Hotel, Restaurants, Pubs) & \\
\hline Dependencies & & & \\
\hline Safety & & Assessment & \\
\hline Cost & & $\begin{array}{l}\text { Assessment of Environment } \\
\text { Restaurants and Beaches }\end{array}$ & \\
\hline
\end{tabular}

Source: Authors based on Crouch and Ritchie (1999), Dwyer and Kim (2003), Sánchez and López (2015), World Economic Forum (2007).

The most extensive work on destination competitiveness has been published by Crouch and Ritchie (1999). The authors have developed a model that embraces a broad range of determining factors. Being that it is essential for destinations to create comparative and competitive advantages, four factors are considered: supporting factors and resources (foundation for building a successful tourism industry), core resources and attractions (primary elements of destination appeal), destination management (activities that can influence the other components) and qualifying determinants (factors that can modify the influence of the previous three elements). All these factors are influenced by internal and external drivers. Later, in 2000, a fifth factor was included: destination policy, planning and development. The ultimate goal and importance of destination competitiveness is, according to the authors, to provide a high standard of living for the residents. This means that it is directly dependent on the level of economic, social and environmental conditions available to its residents. Dwyer and Kim (2003) bring together the main elements of national and firm competitiveness supported by an initial integration of the Crouch and Ritchie (1999) model, but progressively concentrating and emphasizing other aspects, namely recognizing the demand conditions as an important determinant of destination competitiveness. It also recognizes that competitiveness is not an ultimate goal, but an intermediate goal into achieving regional or national economic prosperity. In their model, the following are explicitly acknowledged: the destination's resources (divided into endowed and created resources), situational conditions (forces in the wide external environment that impact competitiveness), destination management (activities of destination management organizations), and demand conditions (three main elements of demand, awareness, perception and preferences) as a means to achieve destination competitiveness and socioeconomic prosperity. Based on the existing representations, Sánchez \& López (2015) developed a model for the Spanish Mediterranean coast where they elect as main indicators factors as tourist arrivals, tourist expenditure and tourist satisfaction and their possible effects on a destination competitiveness. It is expected that higher values should create employment, add value for the economy and increase the country's wealth. The fourth wide range model considered to measure destination competitiveness was undertaken by the World Economic Forum - WEF. Its Travel and Tourism Competitiveness Report - TTCR - includes the Tourism Competitiveness Index - TTCl - and was first published in 2007. Annually edited since then, and comparing 130 economies worldwide, it delivers an overall measure of destination competitiveness aiming to measure factors and policies that make the tourism and travel industry attractive (Mazanec \& Ring, 2011). The TTCl is based on three broad categories: Travel \& Tourism (T\&T) regulatory framework, T\&T business environment and infrastructure and T\&T human, cultural and natural resources. These three broad categories are constituted 
by 14 pillars composed of 72 variables. The model is intended to be used by stakeholders with the objective of unifying work towards the improvement of the industry's competitiveness in its economies.

\section{COMPETITIVTOUR: a model for southern Portugal versus the Mediterranean regions of Spain}

\subsection{Model Positioning}

There is no single or unique set of competitiveness indicators that apply to all destinations at all times as stressed by Dwyer and Kim (2003), and there is no perfect or turnkey solution model. It is an ongoing process and, as pointed by Sánchez and López (2015), it is necessary to develop destination competitiveness models in order to give destination policymakers a useful tool to support decisions that will be beneficial in the long run. All the efforts promote a new insight and all the previous models, including the three analyzed have been criticized. For instance, and according to Mazanec and Ring (2011), there are open discussions on several factors, such as methodological issues, the composition of the indices, the use of variables, the comparability of countries on different development stages, the arbitrary weight of variables, the indices reliability and validity and its usefulness. According to Kayar and Kozak (2010), research to date failed to examine competitive factors from the perspective of how effective they are in determining the competitive position of a destination, or, in other words quantitative studies that aim to rank different competitiveness factors. Kozak and Rimmington (1999) consider that destination competitiveness can be evaluated both quantitatively and qualitatively. Although most of the indices in the tourism literature use quantitative performance (tourist incomes, tourist arrivals...), there is the need to take into account relative qualitative aspects (soft data), namely attributes or items best liked or disliked by tourists, assuming that they will be compared in terms of their experience with other destinations. Dwyer and Kim (2003) pinpoint that, despite the extensive literature on destination competitiveness, no clear definition or model has yet been developed.

Based on some of the previous identified gaps, namely comparability and factors rank to competitiveness, plus the research context explained in the introduction (Algarve territory regional support decision system), the COMPETITIVTOUR model aims to be not just an index but a set of variables that can be interpreted individually to highlight problematic factors in each of the destinations under study providing both a quick global view of the performance of a destination and the possibility to look more deeply into the variables that are affecting the score and access how to improve the ranking. It is orientated to a regular development with a solid historic regional database background, and is able to be adapted to other destinations sharing tourism specialization efforts, thus allowing for new territories and variables to be added/changed. The COMPETITIVTOUR model considers the previous reference models of Crouch and Ritchie (1999), Dwyer and Kim (2003), Sanchéz and Lopéz (2015) and WEF (2007) and includes aspects outlined in more recent studies, such as the destination life cycle, the degree of tourism dependency and the importance to measure competitiveness at a regional scale (Huang \& Peng, 2012; Croes \& Kubickova, 2013). It also includes particular aspects that are meant to reflect the singularities of the Algarve and the 13 Mediterranean regions of Spain (Figure 2), generally known by the beaches\&sun product, easy air accessibility and plenitude of accommodation infrastructures; this is a trilogy for mass tourism and a dilemma when the consolidation stage is achieved along some of the territories of this geographical area of 14 provinces, which in 2013 represents 20.2 million inhabitants, 180.1 million overnight stays and 1.1 million bed-places.

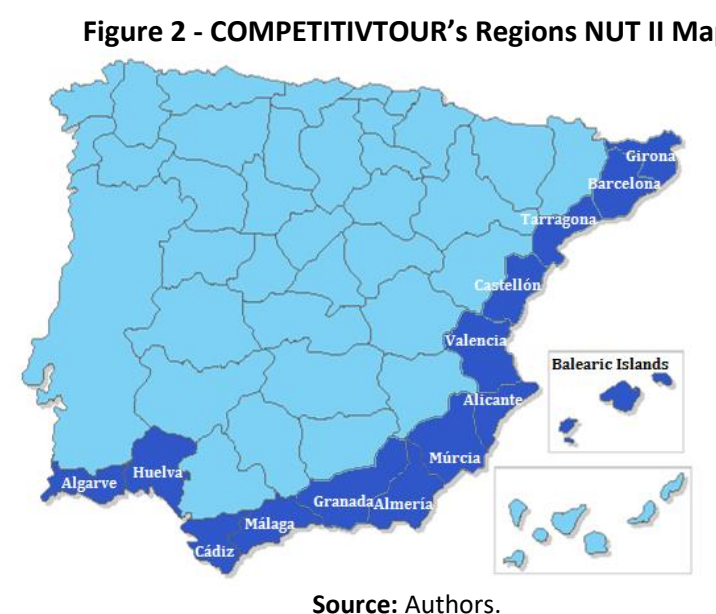

\subsection{Methodology}

Although competitiveness is deeply analysed in tourism literature, as mentioned before, there are several gaps detected in the concepts, namely in the variables that contribute to competitiveness and in what they measure, in the competitiveness models available at the present time. The applied competitiveness model that follows arose out of a coalescence of several research activities and ideas developed in University of Algarve and the regional stakeholders.

The assembly of the model's ground components assumed three main steps, namely: determining which regions to include, selecting performance indicators and finally formulating the competitiveness index. It started with a research in the web sites of a sample of tour operators of each of the Algarve's three main markets (Portugal, United Kingdom and Germany). Then, with an extended list of destinations retailed along with the Algarve, several focus groups with regional planning and tourism representatives were held. During the focus groups the first objective was to select destinations that compete with the Algarve and propose indicators that, according to the literature review, are important in competitiveness assessment. In the second phase, a meticulous research on data availability from official sources and feasibility on a regular basis (annually) was conducted. On a third phase, and with a first essay of the completed model, an international conference on competitiveness was held in the 
Algarve where academics, planning and tourism representatives within the region, as well as international experts, discussed the model and the research team had the opportunity to gather important inputs.

The COMPETITIVTOUR model was first presented in 2009 and has been done every year since. Presently, the model considers 14 regions, Algarve from Portugal and 13 from Spain's Mediterranean coast, respectively Huelva, Cádiz, Málaga, Granada, Almería, Múrcia, Alicante, Valencia, Castellón, Tarragona, Barcelona, Girona and Balearic Islands. In 2013 and 2014 a new territory scale was introduced as an experimental step in the beginning of the process of the model's expansion to new Mediterranean regions, including 5 new destinations from the east and south Mediterranean, respectively Istria (Croatia), Dalmatia (Croatia), Mediterranean Region (Turkey), Souss-Massa_Drâa (Morocco) and Nabeul Governorate (Tunisia). This was a onetime test aiming to attract, in the near future, new scopes and partnerships from the scientific and tourism management community into the model. As it is nowadays the COMPETITIVTOUR uses 25 official sources of information from Portugal and Spain, with the analysis and interpretation supported mainly by statistic descriptive analysis. As shown in Figure 3, the model is composed by three main thematic areas, respectively destination management/situational conditions, resources and products, and market. Each area comprises four tourism related indicators. For each region, these indicators are standardized between 0-1 based on the minimum and maximum values of the indicator along the 14 territories (last column of Figure 3 ).

The first thematic domain, "destination management / situational conditions", combines activities that can enhance the appeal of core resources and attractions (primary motivations), strengthens the quality and effectiveness of the supporting factors and resources (upon which destinations are successfully established), and best adapt to the constraints imposed by the qualifying determinants (factors that define the scale, limit or the potential of a destination). This structure is closely adherent to Crouch and Ritchie's (1999) approach and also considers similar inputs from Zhang's et al. (2011) and Huang and Peng's (2012) works.

Figure 3 - COMPETITIVTOUR Model

\begin{tabular}{|c|c|c|c|c|c|c|c|c|}
\hline Indicator & 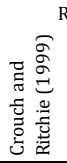 & 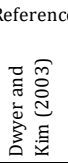 & 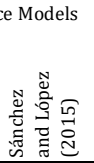 & 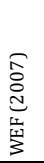 & Description & Observation & Sources & $\begin{array}{l}\text { Index value for each } i \\
\text { region }\end{array}$ \\
\hline \multicolumn{9}{|c|}{ Destination Management / Situational Conditions } \\
\hline $\begin{array}{l}\text { Demographic } \\
\text { Pressure (PD) }\end{array}$ & $\mathrm{x}$ & & & & $\begin{array}{l}\text { Number of overnight stays for } 1.000 \\
\text { inhabitants. }\end{array}$ & $\begin{array}{l}\text { An approach to demand } \\
\text { pressure. }\end{array}$ & $\begin{array}{l}\text { Statistics Portugal; } \\
\text { Statistiscs Spain. }\end{array}$ & $P D_{i}=\frac{\left(P D_{i}-P D_{\min }\right)}{\left(P D_{\max }-P D_{\min }\right)}$ \\
\hline $\begin{array}{l}\text { Average Length } \\
\text { of Stay (AVL) }\end{array}$ & $\mathrm{x}$ & & & & $\begin{array}{l}\text { Average number of nights a tourist } \\
\text { stays in a region. }\end{array}$ & $\begin{array}{l}\text { Expected to be higher in } \\
\text { sun\&sea destinations. }\end{array}$ & $\begin{array}{l}\text { Statistics Portugal; } \\
\text { Statistiscs Spain. }\end{array}$ & $A V L_{i}=\frac{\left(A V L_{i}-A V L_{\min }\right)}{\left(A V L_{\max }-A V L_{\min }\right)}$ \\
\hline $\begin{array}{l}\text { Seasonality } \\
\text { Index (SI) }\end{array}$ & $\mathrm{x}$ & & & & $\begin{array}{l}\text { Ratio between the number of nights in } \\
\text { peak season vs. off-peak season. }\end{array}$ & $\begin{array}{l}\text { Expected to be higher in } \\
\text { sun\&sea destinations. }\end{array}$ & $\begin{array}{l}\text { Statistics Portugal; } \\
\text { Statistiscs Spain. }\end{array}$ & $S I_{i}=\frac{\left(S I_{i}-S I_{\min }\right)}{\left(S I_{\max }-S I_{\min }\right)}$ \\
\hline $\begin{array}{l}\text { Territorial } \\
\text { Pressure (TP) }\end{array}$ & $\mathrm{x}$ & & & & $\begin{array}{l}\text { Number of bed-places for } 1,000 \\
\text { in habitants }\end{array}$ & $\begin{array}{l}\text { Approach to destination's } \\
\text { tourism specialization. }\end{array}$ & $\begin{array}{l}\text { Statistics Portugal; } \\
\text { Statistiscs Spain. }\end{array}$ & $T P_{i}=\frac{\left(T P_{i}-T P_{\min }\right)}{\left(T P_{\max }-T P_{\min }\right)}$ \\
\hline \multicolumn{9}{|c|}{ Resources and Products } \\
\hline Sun\&Sea (SS) & $\mathrm{x}$ & $\mathrm{x}$ & $\mathrm{x}$ & & $\begin{array}{l}\text { Number of beaches awarded with blue } \\
\text { flag in relation with the total number } \\
\text { of beaches available in the destination. }\end{array}$ & Beach quality offer. & (A) & $S S_{i}=\frac{\left(S S_{i}-S S_{\min }\right)}{\left(S S_{\max }-S S_{\min }\right)}$ \\
\hline $\begin{array}{l}\text { Nautical Tourism } \\
\text { (NT) }\end{array}$ & $\mathrm{x}$ & $\mathrm{x}$ & & & $\begin{array}{l}\text { Number of mooring places (offer) in } \\
\text { marinas and recreational ports for } \\
10,000 \text { inhabitants; }\end{array}$ & $\begin{array}{l}\text { Nautical tourism product } \\
\text { density. }\end{array}$ & (B) & $N T_{i}=\frac{\left(N T_{i}-N T_{\min }\right)}{\left(N T_{\max }-N T_{\min }\right)}$ \\
\hline $\begin{array}{l}\text { Accommodation } \\
\text { Occupancy Rate } \\
\text { (AOR) }\end{array}$ & $\mathrm{x}$ & $\mathrm{x}$ & $\mathrm{x}$ & & $\begin{array}{l}\text { Mean capacity of accommodation used } \\
\text { during a specific period (year). }\end{array}$ & $\begin{array}{l}\text { Measures demand vs. } \\
\text { offer. }\end{array}$ & $\begin{array}{l}\text { Statistics Portugal; } \\
\text { Statistiscs Spain. }\end{array}$ & $A O R_{i}=\frac{\left(A O R_{i}-A O R_{\min }\right)}{\left(A O R_{\max }-A O R_{\min }\right)}$ \\
\hline Golf (GS) & $\mathrm{x}$ & $\mathrm{x}$ & $\mathrm{x}$ & & $\begin{array}{l}\text { Number of holes (offer) in golf courses } \\
\text { for 10,000 inhabitants; }\end{array}$ & $\begin{array}{l}\text { Golf tourism product } \\
\text { specialization. }\end{array}$ & (C) & $G S_{i}=\frac{\left(G S_{i}-G S_{\min }\right)}{\left(G S_{\max }-G S_{\min }\right)}$ \\
\hline \multicolumn{9}{|l|}{ Market } \\
\hline $\begin{array}{l}\text { Market Diversity } \\
\text { (MD) }\end{array}$ & & $\mathrm{x}$ & $\mathrm{x}$ & $\mathrm{x}$ & $\begin{array}{l}\text { Total overnight stays from all } \\
\text { destinations less the number of } \\
\text { overnight stays of the top three source } \\
\text { destinations; }\end{array}$ & $\begin{array}{l}\text { Measures the relative } \\
\text { diversification of the } \\
\text { tourism market sources. }\end{array}$ & $\begin{array}{l}\text { Statistics Portugal; } \\
\text { Statistiscs Spain. }\end{array}$ & $M D_{i}=\frac{\left(M D_{i}-M D_{\min }\right)}{\left(M D_{\max }-M D_{\min }\right)}$ \\
\hline $\begin{array}{l}\text { Market } \\
\text { Adjustment } \\
\text { (MA) }\end{array}$ & & $\mathrm{x}$ & & $\mathrm{x}$ & $\begin{array}{l}\text { Ratio between the growth rate of the } \\
\text { demand (overnight stays) and supply } \\
\text { (bed place capacity) over successive } \\
\text { periods of } 3 \text { years. }\end{array}$ & $\begin{array}{l}\text { Market pressure: demand } \\
\text { or supply. }\end{array}$ & $\begin{array}{l}\text { Statistics Portugal; } \\
\text { Statistiscs Spain. }\end{array}$ & $M A_{i}=\frac{\left(M A_{i}-M A_{\min }\right)}{\left(M A_{\max }-M A_{\min }\right)}$ \\
\hline $\begin{array}{l}\text { Accommodation } \\
\text { Prices at Peak } \\
\text { Season (APP) } \\
\end{array}$ & & $\mathrm{x}$ & $\mathrm{x}$ & $\mathrm{x}$ & $\begin{array}{l}\text { Mean price of the } 10 \text { most popular } 4 \\
\text { star hotels in each destination. }\end{array}$ & $\begin{array}{l}\text { Double room with } \\
\text { breakfast included, } 7 \\
\text { days length of stay. }\end{array}$ & www.booking.com & $A P P_{i}=\frac{\left(A P P_{i}-A P P_{\min }\right)}{\left(A P P_{\max }-A P P_{\min }\right)}$ \\
\hline $\begin{array}{l}\text { Seasonal Price } \\
\text { Gap (SPG) }\end{array}$ & & $\mathrm{x}$ & $\mathrm{x}$ & $\mathrm{x}$ & $\begin{array}{l}\text { Difference between the mean price of } \\
\text { the } 10 \text { most popular } 4 \text { star hotels in } \\
\text { each destination in August's firts week } \\
\text { and December first week. }\end{array}$ & $\begin{array}{l}\text { Double room with } \\
\text { breakfast included, seven } \\
\text { days length of stay. }\end{array}$ & www.booking.com & $S P G_{i}=\frac{\left(S P G_{i}-S P G_{\min }\right)}{\left(S P G_{\max }-S P G_{\min }\right)}$ \\
\hline
\end{tabular}

(A) European Blue Flag Association; Visit Algarve; www.playas.es; Turismo de Andalu cía; Turismo de Murcia; Turismo de Comunitat Valenciana; Turismo de Castellon; València Turisme; www.costasur.pt; http://es.costabrava.org/; http://www.spain.info/pt/; http://www.illesbalears.es/.

(B) Statistics Portugal; Statistiscs Spain; Perna, Custódio, Gouveia \& Oliveira (2009); Ajencia Publica de Puertos de Andalucía; http://www.buscoamarre.com/; http://www.illesbalears.es/.

(C) Statistics Portugal; Statistiscs Spain; Algarvegolfe; Turismo de Andalucía; Turismo de Múrcia; Turismo Alicante; Turismo Catellón; Turismo de Valência; Turismo da Catalunha; Turismo de Espanha; http://wwwillesbalears.es/. 
The second thematic domain is "resources and products", a component of the COMPETITIVTOUR model that describes primary and secondary elements of destination appeal, which attends to the factors empathized by Crouch and Ritchie (1999), Dwyer and Kim (2003) and Sánchez and López (2015). It is composed by four different indicators referring sun \& sea nautical tourism, accommodation accupancy and golf. The third and last thematic domain is "market", which combines four different variables or market characteristics, merging some of the main preoccupations about markets' behaviour and prices adapted from characteristics both present in Dwyer and Kim (2003), WEF (2007), Huang and Peng (2012) and Sánchez and López (2015) models, respectively the demand factors and environment and T\&T Business infrastructure. The final COMPETIVTOUR Index value for each region in each period considered is given by the equation:

$$
\text { COMPETITIVTOUR Index Region }{ }_{i}=P D_{i}+A V L_{i}+S I_{I}+T P_{i}+S S_{i}+N T_{i}+A O R_{i}+G S_{i}+M D_{i}+M A_{i}+A P P_{i}+S P G_{i}
$$

The index fluctuates between 0 and 12 , later normalized between 0 and 100 points for graph presentation and interpretation at Figure 4, with the unlikely limits (0 and 100) emerging if a region has the minimum indicator value in all the 12 indicators or, by opposition, if a region has the maximum indicator value along the 12 indicators.

As a result, the COMPETITIVTOUR model can be seen as an index that tries to be as functional and inclusive as possible, regularly applied and closely related to the destination management demands, in which each variable can be individually analysed at a given point or over a set period in order to detect possible situations where management options with implications on tourism destination competitiveness have to be adjusted and re-evaluated.

\subsection{Model application main findings}

The COMPETITIVTOUR model delivers a global competitiveness index based on the relative distance of each variable to the minimum and maximum value observed by that variable along the 14 regions. Assuming an equal ponderation for all the variables, the aggregation of the 12 indicator distances reveals the destination's global competitiveness level within these regions' framework and only between these. The 2013 example results are presented in Figure 4.

Figure 4 - COMPETITIVTOUR 2013 Regional Global Index

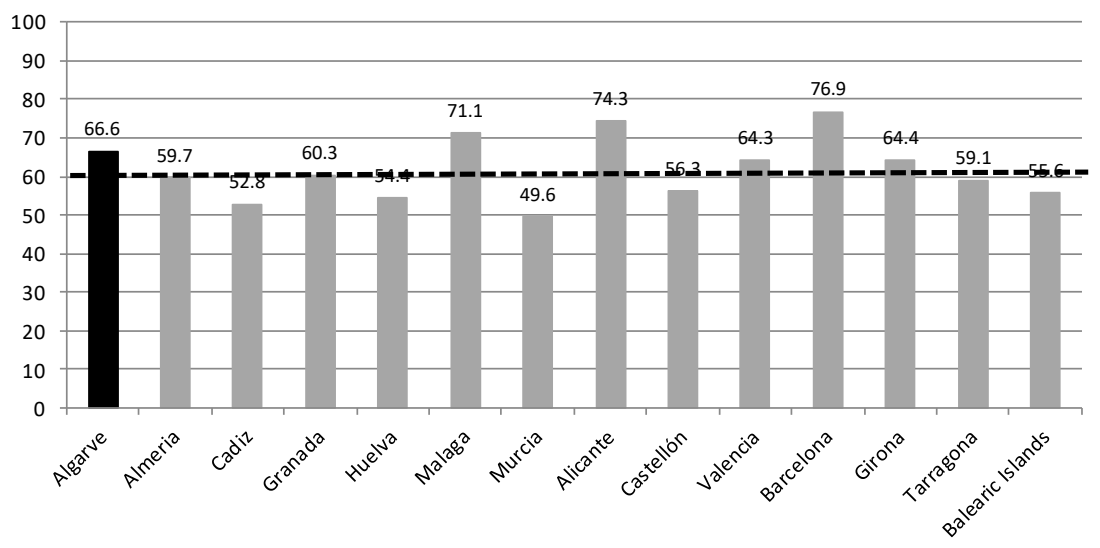

Source: Authors.

The gap between the extremes index values is only 27.3 points, which in a first approach reveals a competitive consistency along these regions. However, as expected, there are differences and sub-groups of regions that should be highlighted. The results evidence the leadership assumed by three regions: Barcelona, Alicante and Malaga. Considering Barcelona a province mostly influenced by the urban and cultural attractions of its capital, it is indeed a competitive leader, but simultaneously an urban outlier in Mediterranean territory based on the context of sun\&sea. The other leaders Alicante and Malaga - are well-known and established seaside cities and resorts strongly attached to the sun/sea product, a profile that, particularly in Malaga, is similar to the Algarve. Despite the good performances in some of the COMPETITIVTOUR indicators, Murcia, Cadiz and Huelva are the regions with the lowest performance, being interesting to note that Cadiz and Huelva are the closest Spanish regions to the Algarve.

As emphasised along the literature review and COMPETITIVTOUR's conceptual positioning and methodology, a global index always suffers from aggregation bias related to indicators' ponderation (or absence of ponderation). Simultaneously, there is a substitution effect among destinations (Bornhorst et al., 2010), which implies that only what is comparable should be compared. Finally, it is an opportunity to examine the competitive factors from the perspective of how effective each one is in influencing the competitive position of a destination (Kayar \& Kozak, 2010), highlighting the main strengths and constrains of destination competitiveness. Within this perspective, the analysis proceeds 
with the highlighting of the three most important problematic/competitive factors detected in the Algarve when compared to the 13 Spanish provinces under study; a detailed knowledge that is assumed in the COMPETITIVTOUR's positioning as having a higher importance for discussion than the unique global result of the index. These three main factors emerge from the observed behaviour of the indicators: seasonality, market adjustment and seasonal price difference. There is an immediate first finding that is the fact that two out of three indicators belong to the market thematic domain. This is also a possible innovative finding, since the first factor, seasonality, is only indirectly assumed in the reference models of a destination's competitiveness. Considering Crouch and Ritchie's (1999) model, the designated competitive advantages of a destination results from the ability to use resources efficiently. In the present research interpretation, efficiency is highly dependent on the linear use of resources throughout the year, hypothesis that is not evident in the analysed literature. It was detected that seasonality is not an obvious object of particular analysis in the destination's competitiveness research, not even emerging among the latest core indicators of a destination's competitiveness model proposed in Dupeyras and MacCallum (2013) work for OECD. For sun\&sea mass tourism destinations, this constitutes an analysis gap emphasized by the Spanish regions of Girona, Tarragona and Balearic Islands, particularly the last two, where seasonality is indeed a constrain for the destination's competitiveness as expressed in Figure 5. High seasonality means less investments return and resources productivity in the off-peak season. Being a typical cycle at tourism destinations it is however one of their main restrictions.

Figure 5 - COMPETITIVTOUR Seasonality Indicator

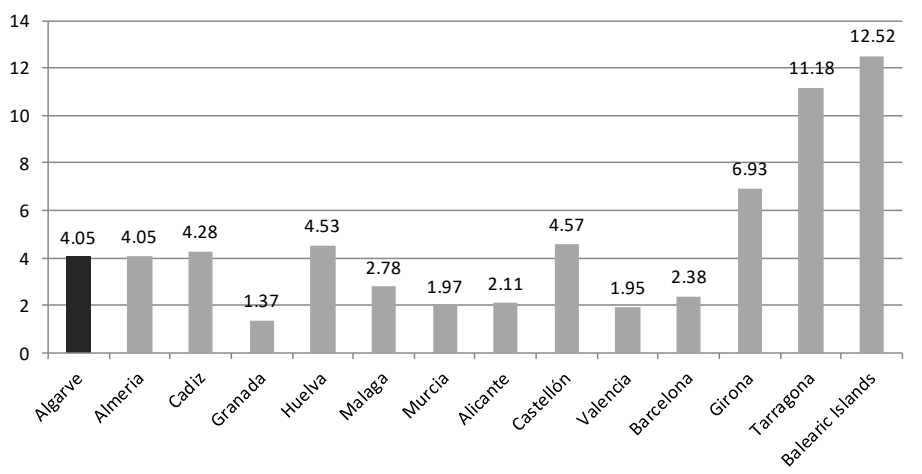

Source: Authors data analysis based on Portugal's Statistics Institute (2016) and Spain's Statistics Institute (2016).

As can be seen in Figure 5, although Algarve is a seasonal destination achieving 4.05 overnight stays in peak season (3rd quarter) for each overnight stay in the off-peak season (1st quarter), it is, however, below the mean value when compared with the Spanish provinces in analysis. Algarve registers a seasonality level similar to the provinces of Almeria, Cadiz, Huelva and Castellón, but much lower than the referred provinces of Girona, Tarragona and Balearic Islands. Although this can be interpreted as a positive result, there is room to improve the outcome as demonstrated by the behaviour of other regions. For example, the province of Malaga is one of Algarve's most important competitors, identified in tour operators' websites and regional stakeholders' workshop(s). Although Malaga is a region devoted to sun\&sea tourism, its level of seasonality is much lower when compared with the one observed in the Algarve. One explanation for this good performance could be the golf product, crucial to capture demand flows outside the summer peakseason. But both Malaga and the Algarve are leaders in terms of the COMPETITIVTOUR golf indicator importance, so this might not explain the seasonality difference. A second possible explanation might emerge from the different source markets' weights, particularly the strongest presence of the national market (Spain) in Malaga tourism demand, with the correspondent possibility for short breaks during the off-peak season or national second home residences enablement. As expected, the urban\&cultural destinations, such as Granada, Valencia and Barcelona, reveal the lowest levels of seasonality, with an interesting figure in Murcia, a fact to be deeply analysed in possible future developments and contacts with local stakeholders, namely because of its contradiction with other findings for this province.

The second key factor to differentiate the competitiveness level is the market adjustment indicator. This indicator promotes the reciprocal analysis of the supply (bed-places) and demand (overnight stays) movements in the Algarve and the other 13 regions, represented in Figure 6 by the growth rates for the period of 2011/2013. The figure is divided into eight possible competitive positions, varying from the least favourable, where both demand and supply growth rates have negative values, particularly negative if the decreasing rate of the overnight stays exceeds the bed places declining value. This creates a market reality where there is an imbalance in the demand/supply, with the pressure on the offer side jeopardizing the destination competitiveness. In opposition, the ideal position is expected to happen when both growth rates, demand and supply, are positive, particularly when the demand growth is higher than the offer. This is a situation that creates a market reality where the destination faces pressure from the demand side, with the consequent space to implement price strategies and assume some risks testing the efficiency of new management options. 
Figure 6 - COMPETITIVTOUR Market Adjustment Indicator

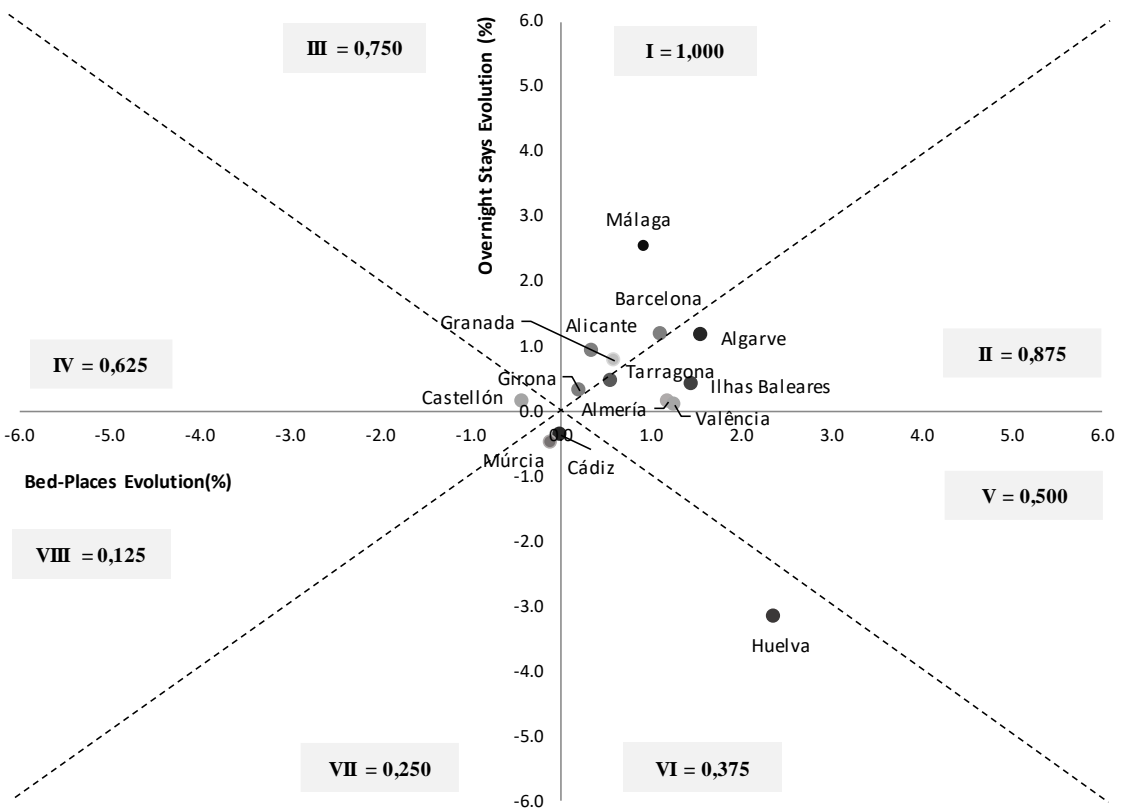

Source: Authors data analysis based on Portugal's Statistics Institute (2016) and Spain's Statistics Institute (2016).

In 2013, although not ideal, Algarve's position in comparison with the 13 provinces in analysis can be considered very positive. Both the demand and supply growth rates in the region were progressive during this period. However, being the supply growth rate slightly higher than the demand growth rate, this relation should be regarded with caution, since the risk of future imbalance is present, namely if lodging investments are assumed with a short-term profitability goal. The destinations that are regarded as the most competitive in the market adjustment variable in the $2011 / 13$ period are Malaga, Barcelona, Alicante and Granada, a list where urban\&cultural destinations are well represented, but with a special remark to Malaga's behaviour, an exception with a particularly positive adjustment performance for a sun/sea destination. On the other hand, Murcia and Cadiz are the worst positioned among 14 regions, with a (minor) decreasing investment and demand growth rates. The third and final key indicator is the seasonal price gap (see Figure 7). Its importance is particularly evident since it is considered that "changing costs in particular destinations relative to others, adjusted for exchange rate variations, are regarded as the most important economic influence on destination shares of total travel abroad (Dwyer, Forsyth \& Rao 2000, p. 9). According to these authors, it is widely accepted that international travellers are sensitive to price, therefore it is important to pay attention to the price competitiveness of a destination's tourism industry compared to its competitors. Being tourism a seasonal industry, a minor price gap between peak and off-peak season might neutralise some of the negative seasonality's economic effects and, in opposition, a bigger price gap will amplify those negative effects.

Figure 7 - COMPETITIVTOUR Seasonal Price Gap Indicator

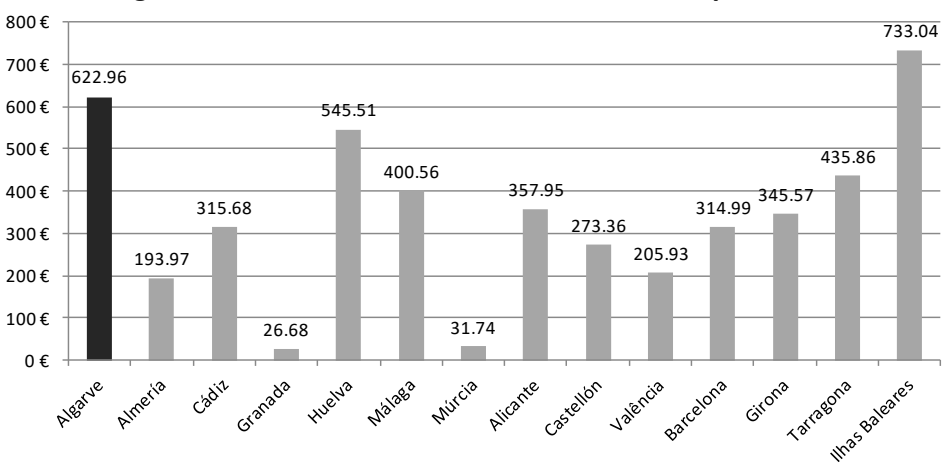

Source: Authors data analysis.

Seasonal Price Gap is a potentially problematic area for the Algarve region, as it has the second highest price gap of the 14 regions, surpassed only by the Balearic Island performance. In the Algarve, exactly the same accommodation and service double room one week with breakfast - costs less $€ 622.96$ in the off-peak season when compared with the peak season, with this 
difference reaching $€ 733.04$ in the Balearic Islands, the highest price gap of the COMPETITIVTOUR regions. It is important to highlight that although the prices registered in the Algarve in the off-peak season represent only one third of the ones registered in peak season, the region still has the lowest annual occupancy rate of all the analysed regions, $40.9 \%$ (Portugal Statistics Institute 2016). If considered the month of December of 2013 (the same month the off-peak season prices refer to), the average region's occupancy rate stood at a worrying $17.0 \%$. It becomes evident that something in the region's winter strategy must be changed, since the lowest prices of the offpeak season match the lowest occupancy rate, a critical loselose situation that compromises the competitiveness levels throughout the year and must be reverted. The relatively average lowest-priced accommodation during the winter is not a decisive factor to attract tourists to the Algarve during this season, otherwise the occupancy rate would be higher. If it is not the price, then what is it? This discussion should be further developed and it is one of the best examples that demonstrate the importance to individually examine the different competitive factors and not simply assume the global aggregate index as this might hide particular and fundamental aspects.

\section{Conclusion}

According to the first objective of the present work and after the literature review and discussion, competition is inherent to societies and tourism destination territories are not an exception. It is assumed that a competitive advantage requires the management's ability to balance the multidimensional components of the tourism system. A share of this management capability depends on decision support systems, in which the information to evaluate and monitor the competitiveness level of a region among its competitors is widely assumed by the tourism literature as critical to the destination's success. As stated, due to the tourism industry singularity, these competitiveness measure instruments - such as the COMPETITIVTOUR model - must be multidisciplinary in order to incorporate the different tourism thematic domains in which destinations play their competitiveness. Simultaneously, they should compare what can be comparable and should be as close to reality as possible. That's why COMPETITIVTOUR assumes the regional level of analysis and is focused on the coastal Mediterranean territories of Spain vs. Algarve.

The paper focuses on an index with a limited number of variables adjusted to the destinations in study and with the objective of being annually applied. It is outlined the importance that the conceptual competitiveness measurement guidelines should not be limited to on a unique index / global ranking, since it can hide important details of reality, details equally or even more important than the overall result itself in understanding what can affect the destination's current position and how to improve performance levels. This is the opportunity to highlight the main strengths and constrains of destination competitiveness, as COMPETITIVTOUR intends to demonstrate for the Algarve tourism reality along the identified geographical context. The results evidence the above average tourism competitiveness performance along COMPETITIVTOUR regions, mainly supported by resources and products thematic domain (particularly sea\&sun beaches quality, golf courses and nautical tourism), and, in the 2011-2013, period by a market adjustment that, after the negative cycle started in 2007 , seems to finally recover by showing positive investment and demand growths.

The main constrain for the Algarve's tourism competitiveness relies on the seasonality level, the fourth highest along the 14 regions, which is amplified by the fact that Algarve also has the second highest accommodation price gap from peak to off-peak season, an identified lose-lose situation with low prices and less tourism. This makes public management extremely critical due to the necessary oversized infrastructures dimension (costs) and the off-peak minimum economic return. Cumulatively, it is also a private management challenge, with the winter flows and revenues frequently not being enough to cover the companies' fixed costs, forcing them to close services, a decision that launches a snowball effect towards destination seasonality growth.

Managing these competitiveness issues will always be a complex and ongoing process. Recovering the position of Dwyer and Kim (2003), there is no single or unique set of competitiveness indicators that apply to all destinations at all times. For the near future and facing the growing importance of quality perception and experience-orientated destinations, the COMPETITIVTOUR research group intends to explore the integration of qualitative indicators into the model, for example a destination's image assessment, and discuss its weight in the determination of destination competitiveness as suggested, among others, by Zhang et al. (2011), Huang and Peng (2012) and Crouch (2011). This effort will be parallel with a model geographical enlargement intention, aiming to bring into the model some Mediterranean destinations outside the Portuguese and Spanish framework. New indicators and new regional partnerships will act as a test to the model theoretical development and results replication, a desired scientific orientated and empirical context that will maintain the model's conceptual coherence and might contribute to the possible generalization objective.

\section{References}

Ayikoru, M. (2015) Destination competitiveness challenges: A Ugandan perspective. Tourism Management, 50, 142-158.

Bornhorst, T., Ritchie, R. \& Sheehan, L. (2010). Determinants of tourism success for DMO \& destinations: An empirical examination of stakeholders' perspectives. Tourism Management, 31, 572-589.

Buhalis, D. (2000). Marketing the competitive destination of the future, Tourism Management, 21, 97-116.

Chien-Minn C., Sheu-Hua, C., Hong-Tau, L. \& Tsung-Hsien, T. (2016). Exploring destination resources and competitiveness-A comparative analysis of tourists' perceptions and satisfaction toward an island of Taiwan. Ocean \& Coastal Management, 119, 58-67.

Croes, R. \& Kubickova, M. (2013). From potential to ability to compete: Towards a performance-based tourism competitiveness index. Journal of Destination Marketing \& Management, 2, 146-154. 
Croes, R. (2011). Measuring and explaining competitiveness in the context of small island destinations. Journal of Travel Research, 50(4), 431-442.

Crouch, G. \& Ritchie, J. (1999). Tourism, competitiveness, and social prosperity. Journal of Business Research, 44, 137-152.

Crouch, G. \& Ritchie, J. (2000). A model of destination competitiveness/sustainability: Brazilian perspectives. Revista de Administração Pública, 44(5), 1049-1066.

Crouch, G. (2011). Destination competitiveness: An analysis of determinant attributes. Journal of Travel Research, 50(1), 27-45.

D'Hauteserre, A. (2000). Lessons in managed destination competitiveness: The case of Foxwoods casino resort. Tourism Management, 21, 23-32.

Dupeyras, A. \& MacCallum, N. (2013). Indicators for measuring competitiveness in tourism: A guidance document, OECD Tourism Papers 2013/02, OECD Publishing.

Dwyer, L. \& Kim, C. (2003). Destination competitiveness: Determinants and indicators. Current Issues in Tourism, 6(5), 369-414.

Dwyer, L., Dragićević, V., Armenski, T., Mihalič, T. \& Cvelbar, L. (2014). Achieving destination competitiveness: an importance-performance analysis of Serbia. Revista de Administração Pública, 44(5), 1049-1066.

Dwyer, L., Forsyth, P. \& Rao, P. (2000). The price competitiveness of travel and tourism: A comparison of 19 destinations. Tourism Management, 21, 9-22.

Enright, M. \& Newton, J. (2004). Tourism destination competitiveness: a quantitative approach. Tourism Management, 25, 777-788.

Go, F. \& Govers, R. (2000). Integrated quality management for tourist destinations: A European perspective on achieving competitiveness. Tourism Management, 21, 79-88.

Hanafiah, M., Hemdi, M. \& Ahmad, I. (2015) Reflections on Tourism Destination Competitiveness (TDC) Determinants. Advanced Science Letters, 21(5), 1571-1574.

Hassan, S. (2000). Determinants of market competitiveness in an environmentally sustainable tourism industry. Journal of Travel Research, 38, 239-245.

Huang, J. \& Peng, K. (2012). Fuzzy Rasch model in TOPSIS: A new approach for generating fuzzy numbers to assess the competitiveness of the tourism industries in Asian countries. Tourism Management, 33, 456-465.

IMPACTUR - Indicadores de Monitorização e Previsão da Atividade Turística (2015). Retrieved January 15th 2015, from http://www.impactur.pt.

Instituto Nacional de Estadística - España (2016). Retrieved January 15th 2015, from www.ine.es.

Instituto Nacional de Estatística - Statistics Portugal (2016). Retrieved January 15th 2015, from www.ine.pt.

Kayar, Ç. \& Kozak, N. (2010). Measuring destination competitiveness: an application of the travel and tourism competitiveness index. Journal of Hospitality Marketing \& Management, 19, 203-216.

Kozak, M. \& Rimmington, M. (1999). Measuring tourist destination competitiveness: Conceptual considerations and empirical findings. Hospitality Management, 18, 273-283.

Mazanec, J. \& Ring, A. (2011). Tourism destination competitiveness: Second thoughts on the World Economic Forum reports. Tourism Economics, 17(4), 725-751.

OECD (2005). OECD Annual Report - 45th anniversary, Paris: OECD.

Porter, M. (1980). Competitive strategy: Techniques for analyzing industry and competitors. New York: Free Press.

Porter, M. (1990). The competitive advantage of nations. London: The Macmillan Press Itd.

Sánchez, A. \& Lopéz, D. (2015). Tourism destination competitiveness: The Spanish Mediterranean case. Tourism Economics, 21(6), 12351254.
Webster, C. \& Ivanov, S. (2014). Transforming competitiveness into economic benefits: Does tourism stimulate economic growth in more competitive destinations. Tourism Management, 40, 137-140.

WEF - The World Economic Forum (2015) Retrieved January 15th 2015, from http://www.weforum.org/.

World Economic Forum (2007). The Travel \& Tourism competitiveness report 2007: Furthering the process of economic development, Geneva: World Economic Forum.

Zhang, H., Gu, C., Gu, L. \& Zhang, Z. (2011). The evaluation of tourism destination competitiveness by TOPSIS \& information entropy - A case in the Yangtze River Delta of China. Tourism Management, 32, 443-451.

Received: 16. February 2017

Revisions required: 28 July 2017

Accepted: 15 October 2017 